\title{
Intrathecally infused antibodies against Nogo-A penetrate the CNS and downregulate the endogenous neurite growth inhibitor Nogo-A
}

\author{
Oliver Weinmann, ${ }^{\mathrm{a}}$ Lisa Schnell, ${ }^{\mathrm{a}}$ Arko Ghosh, ${ }^{\mathrm{a}}$ Laura Montani, ${ }^{\mathrm{a}}$ Christoph Wiessner, \\ Thierry Wannier, ${ }^{\mathrm{c}}$ Eric Rouiller, ${ }^{\mathrm{c}}$ Anis Mir, ${ }^{\mathrm{b}}$ and Martin E. Schwab ${ }^{\mathrm{a}, *}$ \\ ${ }^{a}$ Brain Research Institute, University of Zurich and Department Biology, ETH Zurich, Winterthurerstr. 1908057 Zurich, Switzerland \\ ${ }^{\mathrm{b}}$ Nervous System Research, Novartis Pharma AG, Basle, Switzerland \\ ${ }^{\mathrm{c}}$ University of Fribourg, Institute of Physiology, Fribourg, Switzerland
}

\begin{abstract}
Neutralizing antibodies against the neurite growth inhibitory protein Nogo-A are known to induce regeneration, enhance compensatory growth, and enhance functional recovery. In intact adult rats and monkeys or spinal cord injured adult rats, antibodies reached the entire spinal cord and brain through the CSF circulation from intraventricular or intrathecal infusion sites. In the tissue, anti-Nogo antibodies were found inside Nogo-A expressing oligodendrocytes and neurons. Intracellularly, anti-Nogo-A antibodies were colocalized with endogenous Nogo-A in large organels, some of which containing the lysosomal marker cathepsin-D. This suggests antibody-induced internalization of cell surface Nogo-A. Total Nogo-A tissue levels in spinal cord were decreased in intact adult rats following 7 days of antibody infusion. This mechanism was confirmed in vitro; cultured oligodendrocytes and neurons had lower Nogo-A contents in the presence of anti-Nogo-A antibodies.

These results demonstrate that antibodies against a CNS cell surface protein reach their antigen through the CSF and can induce its downregulation.
\end{abstract}

\section{Introduction}

Antibodies are interesting therapeutic agents due to their high target specificity. CNS targets for therapeutic antibodies in animal experiments or human trials are currently mainly Alzheimer's disease (Gelinas et al., 2004; Hock et al., 2003), neuroinflammatory diseases (Bieber et al., 2000; Goldman et al., 1997; Warrington et al., 2000), tumors (Papanastassiou et al., 1995), spinal cord injury (Schwab, 2004), and stroke (During et al., 2000; Papadopoulos et al., 2002; Wiessner et al., 2003). Nogo-A is a potent neurite growth inhibitory protein present in oligodendrocyte and CNS myelin membranes of the adult CNS and, to a lower degree, on membranes

\footnotetext{
* Corresponding author. Fax: +41 446353303.

E-mail address: schwab@hifo.unizh.ch (M.E. Schwab).
}

of subpopulations of neurons (Dodd et al., 2005; Huber et al., 2002; Hunt et al., 2002; Josephson et al., 2001; Oertle et al., 2003; Wang et al., 2002a,b). Antibodies against Nogo-A applied to the adult CNS via the cerebrospinal fluid (CSF) lead to enhanced regrowth of lesioned axons as well as enhanced compensatory sprouting after spinal cord injury and stroke in adult rats (Schwab, 2004). An impressive degree of functional recovery was often seen in these Nogo antibody-treated animals (Merkler et al., 2001; Papadopoulos et al., 2002; Schwab, 2004; Wiessner et al., 2003; Liebscher et al., 2005).

During CNS development, myelin formation and appearance of Nogo-A in oligodendrocytes parallel the progressive restriction of axonal growth and plasticity (Kapfhammer and Schwab, 1994; Keirstead et al., 1992). In the adult CNS, the most plastic regions are often the lowest in terms of myelin content (Benowitz and PerroneBizzozero, 1991; Kapfhammer and Schwab, 1994). In the postnatal or adult spinal cord and brainstem, suppression of myelin formation or the application of a Nogo-A neutralizing antibody restore plasticity and compensatory sprouting to a level that is normally seen exclusively within the first few days after birth (Dyer et al., 1998; Raineteau and Schwab, 2001; Savio and Schwab, 1990; Schwab, 2004; Thallmair et al., 1998). These results gave rise to the concept of a stabilizing role of Nogo-A for the adult CNS (Kapfhammer and Schwab, 1994; Schwab, 2004), probably assisted by other CNS myelin proteins with neurite growth inhibitory activities like myelin associated glycoprotein (MAG), oligodendrocyte myelin glycoprotein (OMgp), Semaphorin 4D and $5 \mathrm{~A}$, or certain chondroitin sulfate proteoglycans (Filbin, 2003; Moreau-Fauvarque et al., 2003; Goldberg et al., 2004; Niederöst et al., 1999). Whereas data on growth-enhancing effects by in vivo neutralization or gene knockdown are not yet available for MAG or OMgp, Nogo-A knockout (KO) (Kim et al., 2003; Simonen et al., 2003) or application of the monoclonal antibody IN-1 neutralizing Nogo-A led to long-distance regrowth of lesioned adult spinal cord and brain fibers. Enhancement of regeneration and compensatory sprouting was obtained with the IgM antibody IN-1 as well as more recently by new IgG antibodies against Nogo-A (Schnell and 
Schwab, 1990; Brosamle et al., 2000; Merkler et al., 2001; Papadopoulos et al., 2002; Wiessner et al., 2003; Liebscher et al., 2005), by Nogo blocking soluble Nogo receptor fragments ( $\mathrm{Li}$ and Strittmatter, 2003) and by blockade of the Nogo receptor subunit $\mathrm{NgR}$ (GrandPré et al., 2002). All the antibodies neutralize the in vitro neurite growth inhibitory effect of recombinant Nogo-A, of Nogo-A purified from CNS myelin, of crude myelin or brain extracts and of cultured oligodendrocytes. For the in vivo experiments, they were applied as hybridoma grafts or as purified antibodies intracerebroventricularly (icv) or intrathecally (it), but their tissue distribution and fate in the rat CNS have never been studied in detail.

In the present study, we applied different antibodies against Nogo-A into the lateral ventricles or into the subdural space of the spinal cord of adult rats and adult Macaque monkeys. We observed a broad distribution of the antibodies in the brain and spinal cord, and a good penetration in the adult CNS tissue within 7 days also at sites far remote from the infusion sites. In contrast to control antibodies, Nogo-A-specific antibodies were retained in the tissue and were preferentially localized in the Nogo-A expressing cells (oligodendrocytes and neurons). Intracellularly, the antibodies were localized to vacuolar structures which, in part, were labeled with the lysosomal marker Cathepsin-D. In these structures, Nogo antibodies were also colocalized with endogenous Nogo-A, suggesting antibody-mediated internalization and downregulation of the plasma membrane Nogo-A. Indeed, the overall Nogo-A level of the tissue was significantly reduced. The antibodies studied were directed against the Nogo-A-specific region and are strongly neutralizing and growth-enhancing antibodies in vitro and in vivo.

\section{Results}

Tissue penetration and distribution of CSF transported anti-Nogo-A antibodies

The highly specific monoclonal antibodies $11 \mathrm{C} 7$ and 7B12 directed against the Nogo-A-specific region of rat Nogo-A (Oertle et al., 2003) have regeneration enhancing effects in vivo: when infused intrathecally into spinal cord injured rats, they elicited regeneration of sectioned corticospinal tract fibers and enhanced functional recovery in a variety of tasks (Liebscher et al., 2005). Increased functional recovery and enhanced compensatory sprouting were observed in stroke rats as a consequence of mAB 7B12 infusion (Wiessner et al., 2003). As shown in Fig. 1, the antibody $11 \mathrm{C} 7$ and $\mathrm{mAB}$ hNogo-A against the Nogo-A-specific region of human Nogo enhanced growth of neurites on monkey brain extract coated culture dishes in a dose-dependent way.

The antibodies 11C7 and 7B12 were infused into the lateral ventricle of intact adult rats for 7 days by an osmotic mini pump implanted under the back skin of the animals. Immunofluorescence for mouse IgG showed very high signals around the infusion site in the forebrain cortex (Figs. 2b, c). The contralateral side of the brain, the thalamus, midbrain, and medulla oblongata were faintly labeled for the control mouse IgG but showed moderate labeling intensity for the anti-Nogo antibodies 11C7 and 7B12 (Figs. 2a-c). The anti-Nogo antibodies but not the control IgGs were also detectable on the level of the spinal cord (Figs. 2d-f).

In the spinal cord of lesioned rats with intraventricular infusion of antibodies for 7 days, anti-Nogo antibodies were highly accu-
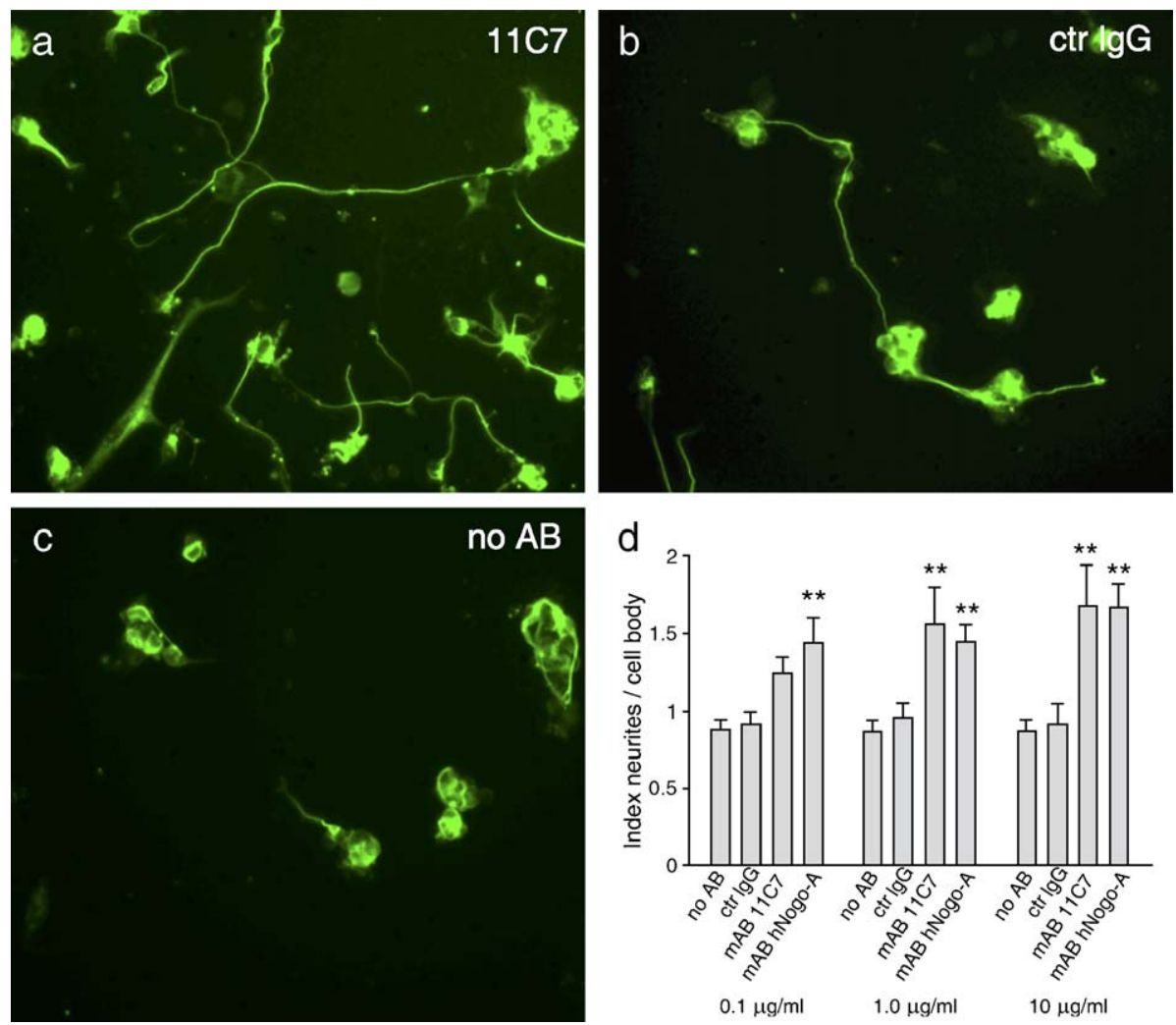

Fig. 1. Monoclonal antibodies against rat Nogo-A (mAB 11C7, 7B12, and human Nogo-A (mAB hNogo-A)) improve neurite outgrowth on culture dishes coated with inhibitory adult monkey brainstem membrane protein extract. P7 rat cerebellar granule cells were grown for 24 h on protein extract coated dishes, preincubated for $30 \mathrm{~min}$ with the respective antibodies at $0.1,1$, or $10 \mu \mathrm{g} / \mathrm{ml}$. $* * P<0.01$. Means \pm SEM of 3 independent experiments. 

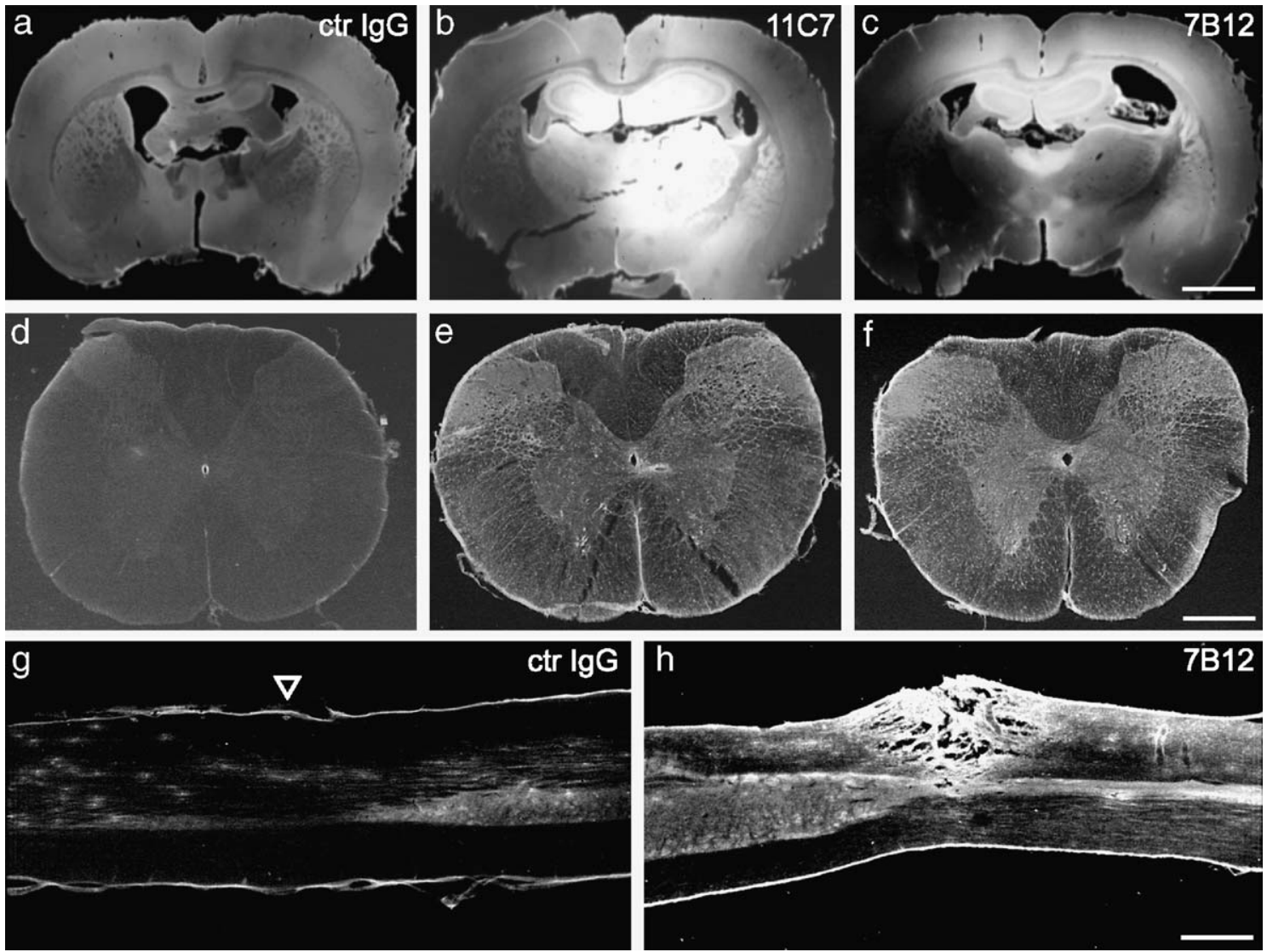

Fig. 2. Intact adult rats were infused into the right lateral ventricle with either a control mouse $\operatorname{IgG}(\mathrm{a}, \mathrm{d})$ or the anti-Nogo-A mAB $11 \mathrm{C} 7$ (b, e), or 7B12 (c, f) for 7 days $(15 \mu \mathrm{g} / \mathrm{h})$. $(\mathrm{a}-\mathrm{c})$ Sections close to the infusion sites. High levels of anti-Nogo-A antibodies are retained in the tissue close to the infusion site; levels of the control mouse IgG are much lower. $(\mathrm{d}-\mathrm{f})$ Cervical spinal cord of the same animals showing a similar difference between anti-Nogo-A and control mABs. The punctuate staining in the anti-Nogo antibody-treated spinal cords corresponds to cell bodies (oligodendrocytes, neurons; see below) labeled by internalized antibodies. Control antibodies (g) or the anti-Nogo-A antibody 7B12 (h) were infused intraventricularly for 7 days into rats with a partial bilateral dorsal spinal cord transection. (g) Sagittal sections of the spinal cord showing very low levels of control antibody, including the lesion site (arrowhead). (h) Anti-Nogo antibodies accumulate in grey and white matter and are enriched at the lesion site. Calibration bar: a-c: $2.1 \mathrm{~mm}, \mathrm{~d}-\mathrm{f}: 0.6 \mathrm{~mm}, \mathrm{~g}, \mathrm{~h}: 0.8 \mathrm{~mm}$.

mulated at the lesion site (Fig. 2h). The adjacent spinal cord grey and white matter regions also contained detectable levels of antiNogo antibodies but not of control antibodies (Figs. $2 \mathrm{~g}, \mathrm{~h}$ ).

In animals with large unilateral strokes, infusion of antibodies into the lateral ventricle of the intact side resulted in high antiNogo-A antibody accumulations at the lesion and the infusion site. Lower but clearly detectable levels of the Nogo-A-specific antibodies but not the control $\mathrm{IgG}$ were detectable in the CNS tissue remote from the lesion site (data not shown).

Antibodies were also infused intrathecally by a subdural catheter pushed up from the spinal column level L2 to the midthoracic region in intact adult rats. Close to the infusion site, all antibodies were detectable in the tissue, but the anti-Nogo antibody levels were higher than those of the control IgG (Figs. 3a, d, g, k). In the cervical spinal cord of these animals, about $2.5 \mathrm{~cm}$ rostral to the infusion site, after 7 days of continuous infusion clear labeling of the spinal cord grey and white matter was observed in the case of the Nogo-Aspecific antibodies, but not for the control antibody (Figs. 3b, e, h, 1). Spinal cord surface and central canal were more strongly labeled. In the forebrain, surface and ventricular labeling as well as clear labeling of the parenchyma was detected for the anti-Nogo antibodies in these spinally infused animals (Figs. 3c, f, i, m).

In the two adult Macaque monkeys infused by a subdural catheter at cervical level C6 for 8 days with the humanized antibody hNogo-
A, the spinal cord was analyzed at the infusion site and $6 \mathrm{~cm}$ caudal to it. High levels of human antibody were present at the infusion site (Fig. 4a). Caudally in the thoracic spinal cord, the central canal and cord surface were strongly labeled, and grey and white matter showed a homogenous labeling which was specific and clearly over background (Figs. 4b, e). A similar situation was present in the forebrain: strong labeling of surface and ventricles and good penetration of the Nogo-A antibody into the parenchyma (Figs. 4c, f).

These experiments show that intraventricular or spinal intrathecal infusion of antibodies against a CNS cell surface antigen lead to an excellent distribution of the antibody through the CSF circulation and the brain and spinal cord tissue in adult rats and monkeys. Whereas the control IgG was washed out rapidly, antibodies against Nogo-A were retained in the tissue.

\section{CSF anti-Nogo-A antibodies label oligodendrocytes and subtypes of neurons}

Low magnifications of white matter of rats with anti-Nogo-A antibodies circulating for 7 days in the CSF showed a punctuate staining which closely resembled the distribution of oligodendrocyte cell bodies (Figs. 2e, f, Figs. 5e, f). This staining was observed in the corpus callosum as well as in the spinal cord after intraventricular infusions and in the spinal cord after spinal intrathecal 

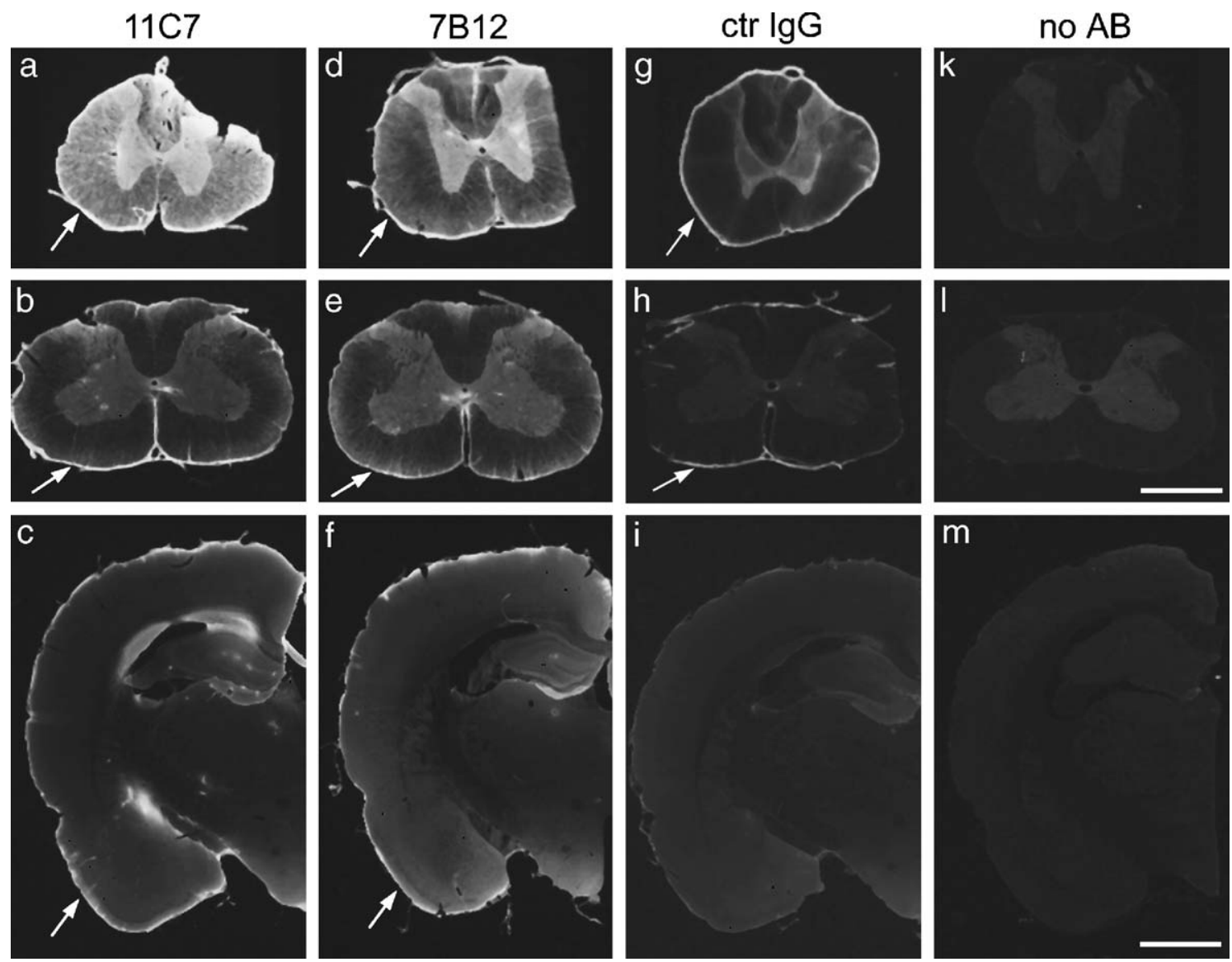

Fig. 3. Spinal cords and forebrains of non-lesioned adult rats infused for 7 days at $15 \mu \mathrm{g} / \mathrm{h}$ intrathecally over the thoracic spinal cord with the anti-Nogo antibodies $11 \mathrm{C} 7(\mathrm{a}-\mathrm{c})$ or 7B12 $(\mathrm{d}-\mathrm{f})$, or with a control mouse $\operatorname{IgG}(\mathrm{g}-\mathrm{i})$. Panels $(\mathrm{k}-\mathrm{m})$ show animal without infused antibody. Labeling is strongest at the infusion site (a, d, g, k), where also the control IgG can be seen (g: compare to spinal cord without infused antibodies: $\mathrm{k}$ ). (b, e, h, 1$) 2.5 \mathrm{~cm}$ rostral to the infusion site and, somewhat less conspicuously, in the forebrain (c, f, i, m) anti-Nogo antibodies (b, c, e, f) show a clearly visible tissue staining, in contrast to the faint presence of the control $\operatorname{IgG}(\mathrm{h}, \mathrm{i})$. The CNS surface is most strongly labeled (arrows). Calibration bar: $\mathrm{a}-\mathrm{k}, \mathrm{b}-1: 1 \mathrm{~mm}, \mathrm{~m}: 2.2 \mathrm{~mm}$.

infusions of the anti-Nogo antibodies $11 \mathrm{C} 7$ and 7B12. Hybridoma grafts in the parietal cortex secreting the antibody IN-1 (but not grafts secreting the control anti-HRP-antibody) also labeled a high proportion of the cell bodies in white matter (Figs. 6a-c).

To identify the white matter cells labeled by the anti-Nogo-A antibodies, we performed double immunostainings. In the white matter, frequent overlap of the infused Nogo antibodies with staining for endogenous Nogo-A (Figs. $5 \mathrm{~g}-\mathrm{i}$ ) or CNPase (not shown), both markers for oligodendrocytes (Huber et al., 2002; Wang et al., 2002a,b), was observed. In contrast, GFAP-positive astrocytes were consistently negative for anti-Nogo antibody staining (Fig. 5k).

In grey matter, in addition to small cell bodies resembling oligodendrocytes, typical and conspicuous neurons, e.g., pyramidal cells in the neocortex or motoneurons in the spinal cord, were labeled by the anti-Nogo-A antibodies (Figs. 5a-f). Often, the antibody appeared in intracellular granules, suggesting uptake (see below). Subtypes of neurons, especially large projection neurons, are known to express Nogo-A and are, therefore, able to bind and internalize the respective antibodies specifically.

\section{Anti-Nogo antibodies are internalized in vacuoles and lysosomal structures}

High-magnification immunofluorescence and confocal microscopy revealed that much of the anti-Nogo antibodies in oligoden- drocytes and neurons were present in relatively large granular structures in the cell body, where they accumulated around the nucleus (Fig. 6). Double immunofluorescence with the lysosomal marker cathepsin-D revealed that a proportion of these anti-Nogo antibody containing granules were lysosomes (Figs. 6d, f). As cathepsin-D is a marker for the more mature lysosomes, some of the cathepsin-D negative antibody containing structures may be prelysosomal bodies and early endosomes.

\section{Endogenous Nogo-A colocalizes with internalized anti-Nogo antibodies in intracellular vacuoles}

Endogenous Nogo-A was labeled by a rabbit antiserum, whereas the infused mouse anti-Nogo-A antibodies $11 \mathrm{C} 7,7 \mathrm{~B} 12$ or IN-1 were visualized with a labeled secondary anti-mouse antibody. In double immunofluorescence, many of the intracellular granules which contained internalized anti-Nogo antibodies were also positive for endogenous Nogo-A (Fig. 7). Oligodendrocyte cell bodies and neurons showed intracellular Nogo-A staining in the endoplasmic reticulum as shown earlier (Chen et al., 2000; Huber et al., 2002). The colocalization of internalized anti-Nogo antibodies with endogenous Nogo-A in structures resembling lysosomes or prelysosome organelles suggests that the anti-Nogo antibodies bind to cell surface Nogo and are internalized subsequently as antibodyligand complexes. 

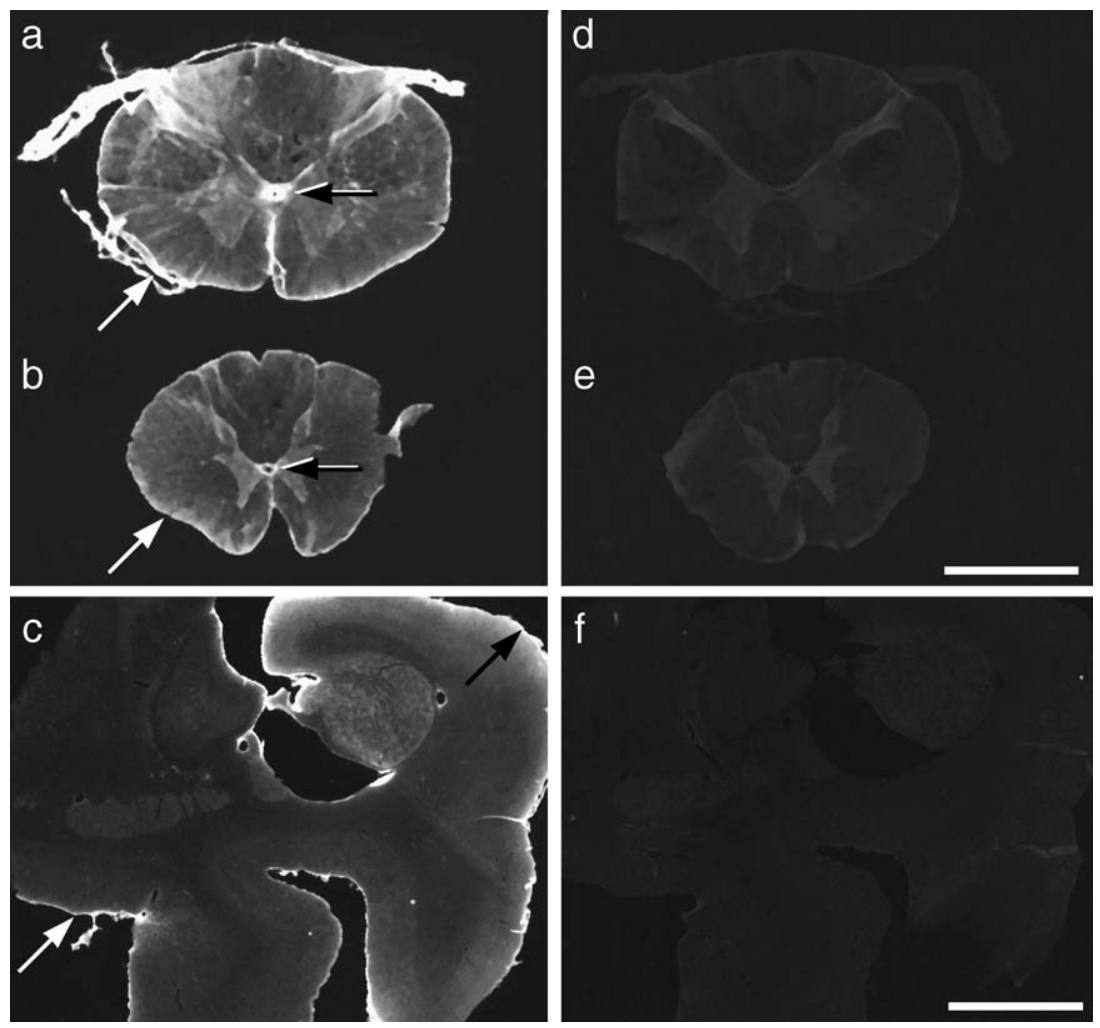

Fig. 4. Sections of cervical (a, d) and thoracic (b, e) spinal cord and forebrain (c, f) of adult Macaque monkey infused intrathecally with a humanized antihuman Nogo-A antibody for 7 days. High levels of the anti-Nogo-A antibody are visible throughout the cervical spinal cord close to the infusion site (a), as well as in the thoracic spinal cord $6 \mathrm{~cm}$ caudal to the infusion site (b). The antibody also reaches and penetrates into the large forebrain of this animal (c). Central canal and CNS surface are most strongly labeled (arrows). Staining is specific as seen by omitting the secondary antibody on adjacent sections (d-f). Calibration bars: a, b, d, e: $3 \mathrm{~mm}$; c, f: $5 \mathrm{~mm}$.

\section{Endogenous Nogo-A levels are reduced in Nogo-antibody infused spinal cord}

Spinal cord cross-sections of intact and spinal cord injured rats were analyzed by immunohistochemistry and Western blots for their endogenous Nogo-A levels, following a 7-day intrathecal infusion of the anti-Nogo-A antibodies $11 \mathrm{C} 7$ or $7 \mathrm{~B} 12$. In intact rats total tissue Nogo-A immunoreactivity as seen by immunofluorescence was reduced to about $70 \%$ if compared to the control IgG infused animals (Figs. 8h, i, 1). The effect required a concentration of $3 \mathrm{mg} /$ $\mathrm{ml}(15 \mu \mathrm{g} / \mathrm{h})$ of infused anti-Nogo antibody $11 \mathrm{C} 7$ (Fig. 71). MAG, which is partially colocalized with Nogo-A in the innermost myelin membrane and shares the receptor subunit NgR with Nogo, was not affected by the Nogo antibodies (Fig. 81). Results using Western blots confirmed a corresponding antibody-mediated downregulation of the Nogo-A levels (Figs. 8m, 1). In injured spinal cords, a similar downregulation of endogenous Nogo-A occurred (data not shown), also in the regions caudal to the lesion where earlier studies observed axonal regeneration (Brosamle et al., 2000; Liebscher et al., 2005).

\section{Prolonged exposure of cultured neurons or oligodendrocytes to anti-Nogo antibodies induces downregulation of Nogo- $A$}

In order to confirm the in vivo observations of endogenous Nogo-A downregulation in response to Nogo-A neutralization, in vitro experiments were done on hippocampal neurons and oligodendrocytes. E18 rat hippocampal neurons were grown as dissociated cultures for 2 weeks in the presence of the anti-NogoA antibody $11 \mathrm{C} 7$ or control IgG. Endogenous Nogo-A immunoreactivity at the cell body, quantified through densitometry, dropped by $30 \%$ in presence of $11 \mathrm{C} 7$ when compared to the control treatment (Figs. 8a-e). Optic nerve derived oligodendrocytes, cultured for 4 days in the presence of $11 \mathrm{C} 7$ responded similarly, showing a downregulation of $50 \%$ of their Nogo-A level (Fig. 8e).

\section{Discussion}

The present results, based on immunohistochemistry combined with specific cellular markers, show a surprisingly good penetration of antibodies against Nogo-A into the spinal cord and brain tissue of adult rats and Macaque monkeys following intraventricular or spinal intrathecal pump infusions. Penetration from the inner and outer liquor spaces into the tissue resulted in clearly detectable antibody levels within 7 days. Anti-Nogo-A antibodies were specifically retained in the tissue and taken up by Nogo-A expressing cells, i.e., oligodendrocytes and subtypes of neurons. Intracellularly, colocalization with endogenous Nogo-A suggests internalization of an antibody-ligand complex. Part of the internalized antibodies colocalized with lysosomal markers suggesting subsequent degradation. Indeed, endogenous Nogo-A levels were significantly decreased in the anti-Nogo antibody infused rat spinal cord tissue.

Intrathecal drug delivery is a clinical routine method especially for anti-spastic drugs and treatment of intractable pain (Stempien 

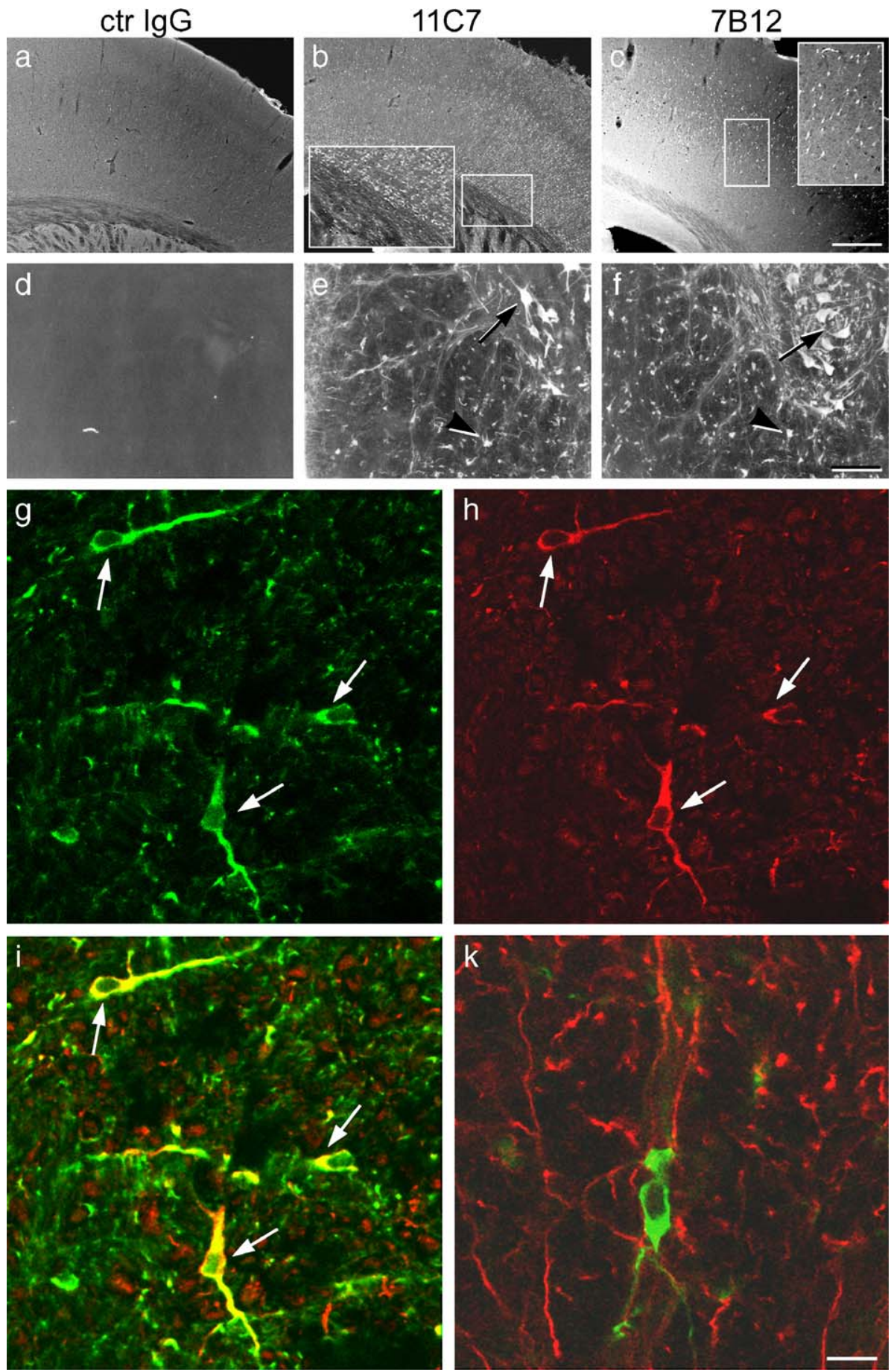

Fig. 5. Anti-Nogo-A antibodies are internalized by oligodendrocytes and neurons. (a-c) Cortex of intact rat brain infused intraventricularly with control (a) or anti-Nogo-A antibodies (b, c). In panel (c), labeling of neuronal cell bodies with shape and position typical for pyramidal cells (insert) can be seen. (d-f) Spinal cord ventral horn with typical large motoneurons (arrows) and ventral white matter oligodendrocytes (arrowheads). Control IgG infused animals show no labeling (d). Anti-Nogo-A antibody infused animals (e, f) show large motoneurons containing anti-Nogo antibodies and in white matter many small labeled cell bodies resembling oligodendrocytes. ( $\mathrm{g}-\mathrm{i}$ ) Three cell bodies (arrows) and a large number of cellular processes in spinal cord white matter of a rat infused intraventricularly for 7 days with the 11C7 anti-Nogo antibody contain the mouse IgG (green, g). All three cell bodies and several of the processes are identified as oligodendrocytes by their content of endogenous Nogo-A (h). (i) Overlap of panels (g) and (h-k) GFAP-positive astrocyte (green) does not overlap with anti-Nogo-A antibody containing structures (red) in the spinal cord white matter of an intraventricularly infused rat. Calibration bars: a-c: $1 \mathrm{~mm}, \mathrm{~d}-\mathrm{f}: 0.1 \mathrm{~mm}$, g-k: $20 \mu \mathrm{m}$.

and Tsai, 2000; Turner, 2003). Pumps catheters enter the lumbar liquor sac from where the drugs flow toward the brain in the outer, subdural liquor space. Distribution of therapeutic antibodies following intraventricular or intrathecal injections or infusions has not been studied so far. Biological effects were seen with radioimmunoconjugated antibodies against tumours (Papanastas- 

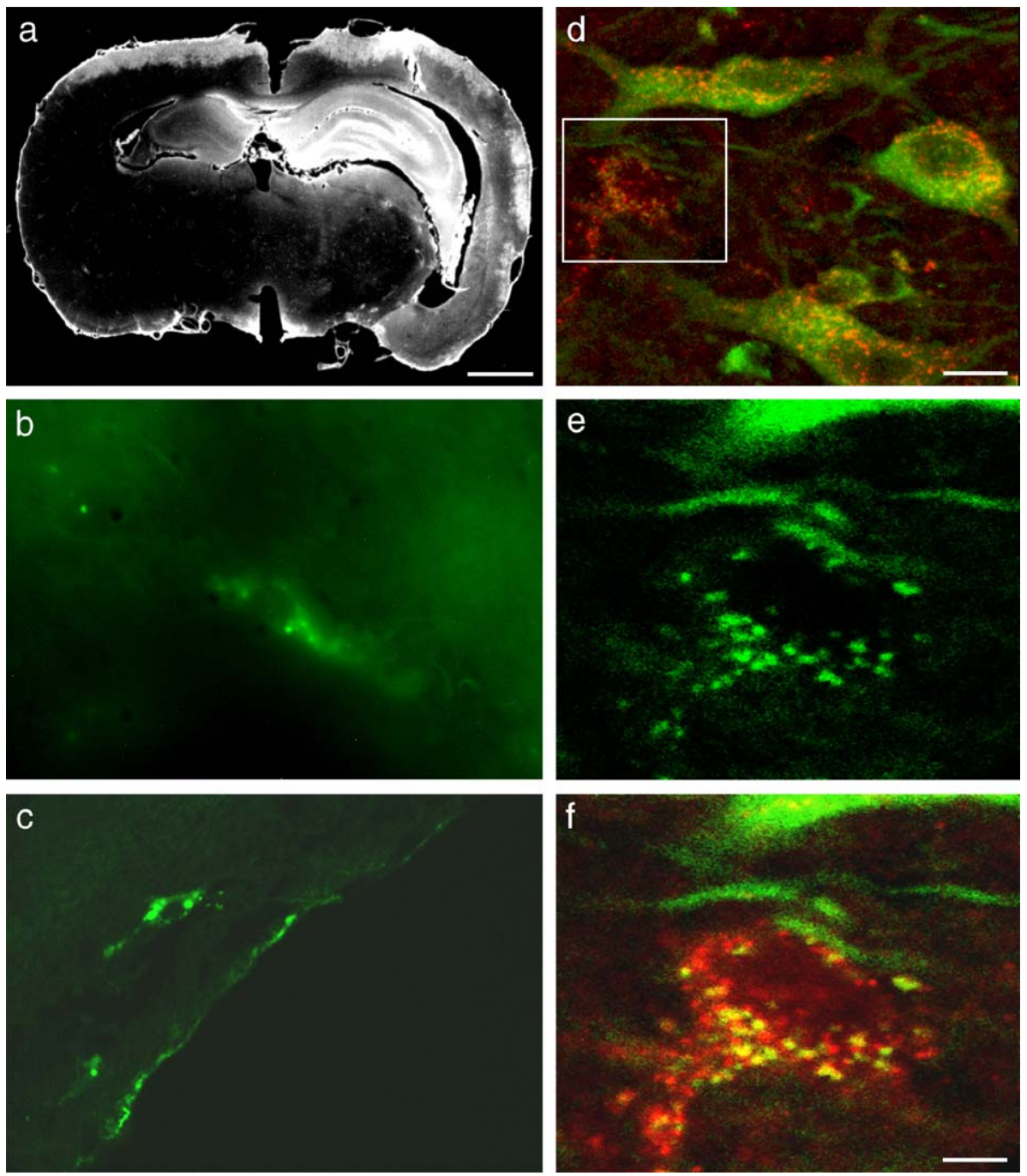

Fig. 6. Infused anti-Nogo antibodies accumulate in vacuolar organelles containing in part the lysosomal marker cathepsin-D. (a) Section of rat forebrain taken several mm caudal to a hybridoma graft secreting the antibody IN-1. (b) IN-1 inside a cell in the corpus callosum from the brain shown in panel (a). The antiNogo antibody appears in granular structures. (c) Corpus callosum cell from a rat infused intraventricularly with antibody 7B12 which appears in large granular structures in the perinuclear area. (d) Large spinal cord motoneurons double labeled for bound/internalized 7B12 antibody (green) and the lysosomal marker cathepsin-D (red) in an intact rat infused for 7 days with 7B12 intraventricularly. (e, f) Higher magnification of single motoneuron boxed in (d): 7B12 antibody (e) and overlay with cathepsin-D (f). Calibration bars: a: $2.5 \mathrm{~mm}, \mathrm{~b}, \mathrm{c}, \mathrm{e}, \mathrm{f}: 2.5 \mu \mathrm{m}, \mathrm{d}: 10 \mu \mathrm{m}$.

siou et al., 1995) and antibodies against bacterial determinants in meningitis after intraventricular or intracysternal application in humans (Goldman et al., 1997). In the rat, intraventricular injections of antibodies against the low affinity NGF receptor p75 resulted in labeling of p75-positive neurons (Thomas et al., 1991). In spite of the known rapid turnover of IgGs in the CSF (Zhang and Pardridge, 2001), the present results show that antiNogo-A IgGs infused into the lateral ventricle or into the spinal subdural liquor space reach the entire CSF circulation and diffuse well into grey and white matter of the whole neuroaxis. This is true in the rat brain as well as following intrathecal infusion in the much larger Macaque monkey brain and spinal cord. Intrathecal or intraventricular delivery, therefore, seems an excellent system for the application of therapeutic antibodies to the CNS. In contrast, earlier studies showed that circulating systemic antibodies against Nogo-A penetrated very poorly into the CNS due to a rapid resealing of the blood-brain barrier (Merkler et al., 2003).
Tissue labeling was weak for the control IgG and much higher for the anti-Nogo-A antibodies. Specific anti-Nogo antibodies are probably retained in the tissue by binding to Nogo-A on the cell surface of oligodendrocytes, CNS myelin, and subtypes of neurons (Dodd et al., 2005; Huber et al., 2002; Oertle et al., 2003; Wang et al., 2002a,b; Huber et al., 2002). Higher magnification analysis showed that all the three anti-Nogo-A antibodies used (11C7 directed against aa $623-640 ; 7 \mathrm{~B} 12$ directed against aa $760-820$ and IN-1 recognizing the Nogo-A-specific region aa173-979) were internalized in granular structures in the cell bodies of oligodendrocytes and neurons. Internalization of antibodies binding to cell surface constituents is a very frequent reaction of cells in vitro and vivo; typically, the antibodies are internalized as a complex together with their binding partners (Charles et al., 2000; Qian et al., 1997; Tolbert and Lameh, 1998; Friedman et al., 2005). The observed colocalization of the infused anti-Nogo antibodies with endogenous Nogo-A in the same granular structures suggests that this mechanism is also operating here. The dimension of these 

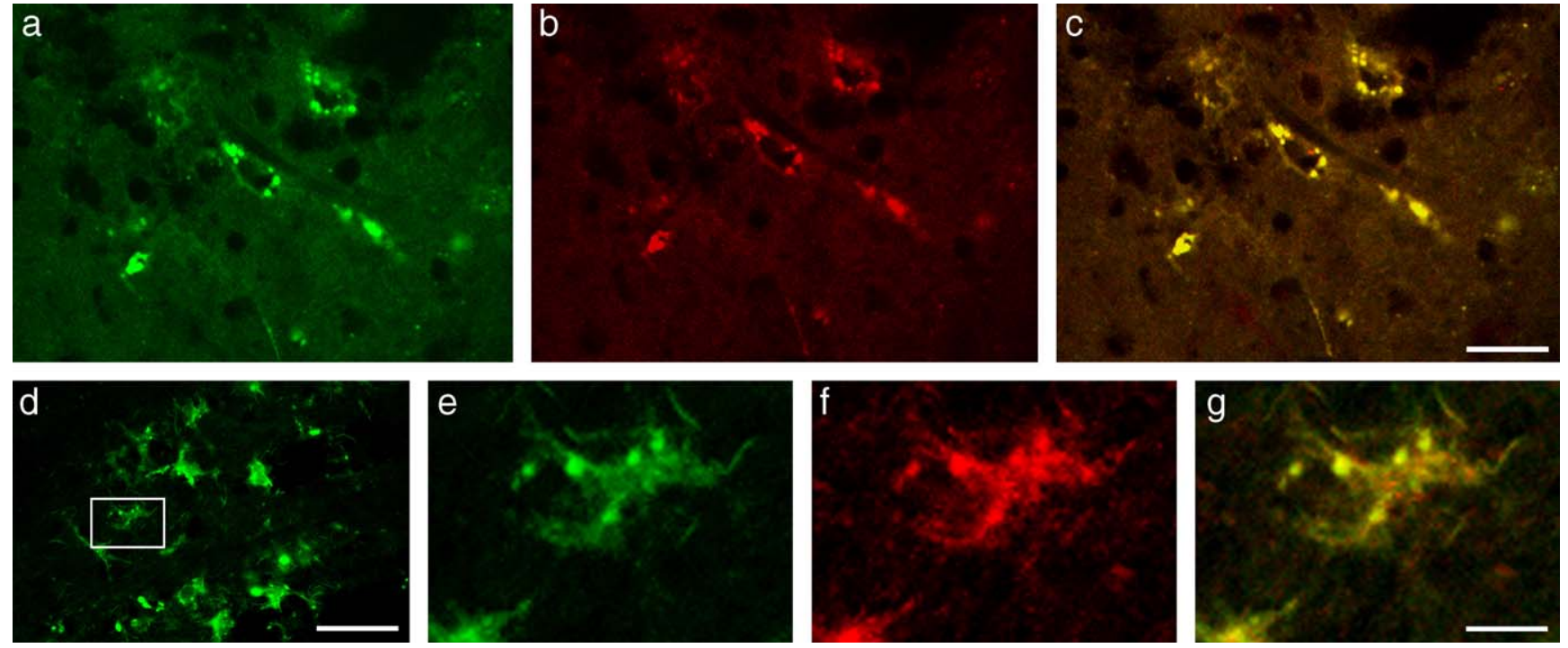

Fig. 7. Neurons in the hippocampus $(\mathrm{a}-\mathrm{c})$ and cells in the corpus callosum $(\mathrm{d})$ of rats infused intraventricularly for 7 days with the antibody $7 \mathrm{~B} 12$ (a-c) or treated with a IN-1 antibody secreting hybridoma graft (d). Internalized anti-Nogo antibodies (green) colocalize with endogenous Nogo-A (red, b, c, f, g) in the same intracellular organelles in hippocampal neurons $(a-c)$ and corpus callosum oligodendrocytes $(d-g)$. (e-g) High magnification view of a single cell boxed in panel (d). Results suggest cointernalization of an antibody-ligand complex. Calibration bars: a-c: $10 \mu \mathrm{m}, \mathrm{d}: 18.4 \mu \mathrm{m}, \mathrm{e}-\mathrm{g}: 3.3 \mu \mathrm{m}$.

granules is that of secondary lysosomes and large endosomes; indeed, some of these structures were labeled with the late lysosomal marker cathepsin-D (Delbruck et al., 1994). The binding of four different antibodies against the Nogo-A-specific region of Nogo-A in vivo also strongly confirms earlier in vitro data showing that this region is indeed exposed on the extracellular side of the membrane (Dodd et al., 2005; Oertle et al., 2003). This feature is important as one of the most potent active inhibitory sites of Nogo$\mathrm{A}$ is found in the middle of the Nogo-A-specific region, and uncertainties existed initially with regard to the topology of the Nogo-A protein in the membrane due to its lack of a canonical Nterminal signal sequence (Chen et al., 2000; GrandPré et al., 2000; Oertle et al., 2003).

Antibody-induced internalization and subsequent lysosomal degradation of Nogo-A could affect the protein levels and its availability for receptor interactions and neurite growth inhibitory functions. We found that infusion of anti-Nogo-A antibodies for 7 days induced a dose-dependent downregulation of the overall NogoA immunoreactivity in the intact and in injured rat spinal cord. Downregulation of cellular Nogo-A could also be observed in vitro: cultures of optic nerve oligodendrocytes or hippocampal neurons lost $30-50 \%$ of their Nogo-A immunoreactivity by prolonged exposure to the anti-Nogo-A antibody 11C7. Whether this effect is entirely due to enhanced, antibody-induced degradation of Nogo-A leading to lowering of the intracellular stores, or whether the synthesis of Nogo-A is also affected remains to be studied. The downregulation was specific for Nogo-A; in the spinal cord, the myelin protein MAG, which is partially colocalized with Nogo-A in the ad-axonal inner myelin membrane (Trapp et al., 1984) has neurite growth inhibitory activity in vitro (McKerracher et al., 1994; Mukhopadhyay et al., 1994) and shares a receptor subunit (NgR) with Nogo (Domeniconi et al., 2002; Liu et al., 2002; Wang et al., 2002a,b) was unaffected. The observed decrease of Nogo-A levels may be of relevance for the in vivo mechanism of action of antibodies against Nogo-A in promoting neurite growth following lesions: in addition to a direct neutralizing effect by binding to and sterically covering the active sites of Nogo, a fraction of cell surface Nogo-A is directly removed by antibody-induced internalization and subsequent degradation. The long distance regeneration of lesioned spinal axons and the widespread occurrence of compensatory sprouting following spinal, brainstem or cortical lesions in antiNogo antibody-treated animals (Schnell et al., 1990; Brosamle et al., 2000; Merkler et al., 2001; Schwab, 2004; Raineteau and Schwab, 2001; Wiessner et al., 2003; Papadopoulos et al., 2002) are in line with the wide distribution of the CSF anti-Nogo-A antibodies.

In conclusion, the present results show that therapeutic antibodies against a CNS cell surface protein infused into the intact or lesioned spinal cord or brain CSF compartment are distributed throughout the CNS, bind to their antigen, and induce internalization and degradation of the antibody-antigen complex. In this way, antibodies against Nogo-A lead to a downregulation of the CNS Nogo-A levels, a process which may contribute to the regeneration and plasticity enhancing effects of anti-Nogo-A antibodies in animals with spinal cord lesions or cortical strokes.

Fig. 8. Downregulation of endogenous Nogo-A levels by anti-Nogo-A antibodies in vitro (a-e) and in vivo (f-m). (a-e) Cultured rat optic nerve oligodendrocytes $(\mathrm{a}, \mathrm{b})$ and E17 hippocampal neurons $(\mathrm{c}, \mathrm{d})$ show decreased endogenous Nogo-A immunoreactivity after exposure to the antibody $11 \mathrm{C} 7$ for 4 days (b) or 14 days (d). Single cell densitometry is shown in e ( $n=30-40$ cells for each experimental condition). (f-k) Spinal cord white matter of intrathecally infused intact adult rats showed no change in the levels of the astrocyte marker GFAP (f, g), but a conspicuous loss of endogenous Nogo-A immunoreactivity $(\mathrm{h}, \mathrm{i}, \mathrm{l})$ by the infusion of anti-Nogo antibodies $11 \mathrm{C} 7$ or $7 \mathrm{~B} 12$ in contrast to the control IgG. Quantification of these results in (1) by densitometry. Note the unaffected levels of MAG. (k) Downregulation of rat spinal cord Nogo-A after 7 days of mAB $11 \mathrm{C} 7$ infusion requires $15 \mu \mathrm{g} / \mathrm{h}(3$ $\mathrm{mg} / \mathrm{ml} ; 5 \mu \mathrm{l} / \mathrm{h}$ ) as an effective minimal antibody dose. (m) Spinal cord Nogo-A protein shown by Western blot after 7 days of $11 \mathrm{C} 7$ infusion at $3 \mathrm{mg} / \mathrm{ml}$. Quantitative data in panels $\mathrm{k}$ and 1 show means \pm SEM of $3-4$ animals per group. $* P<0.05, * * P<0.01$ in two-tailed unpaired $t$ test. Calibration bars: a, f-i: $20 \mu \mathrm{m}$. 
ctr lgG
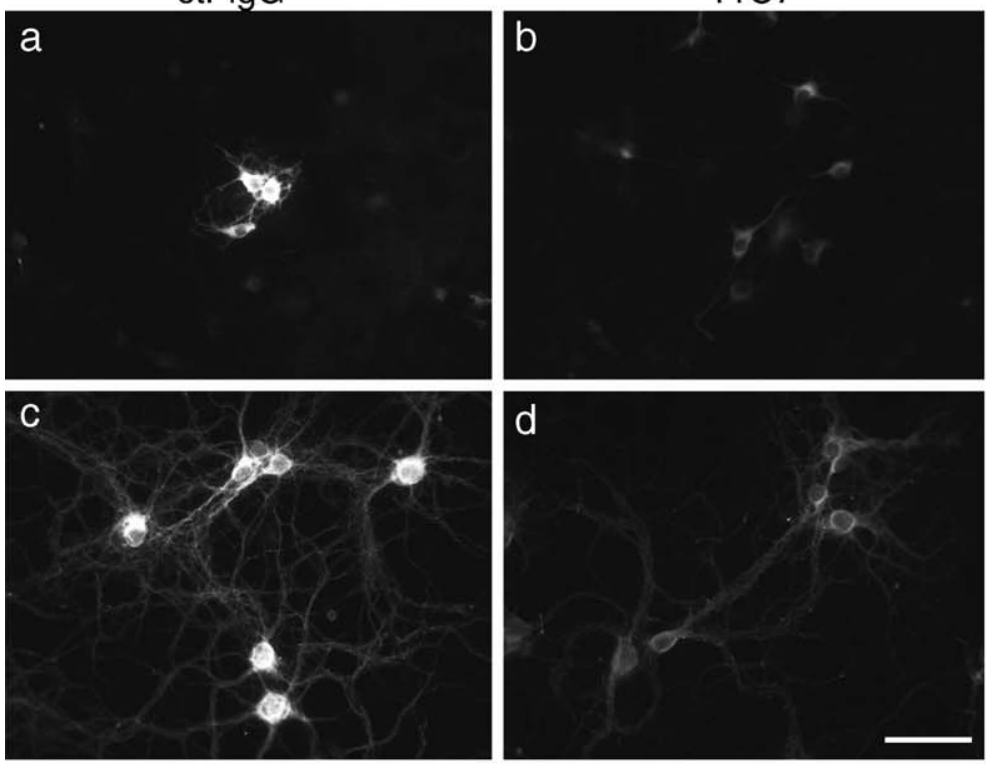

e Downregulation in vitro

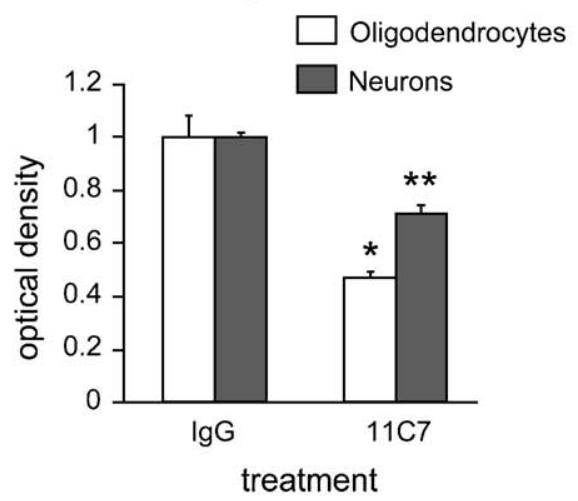

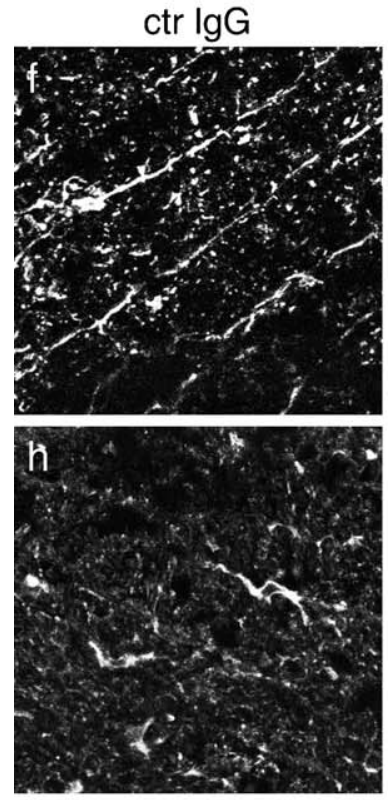

।

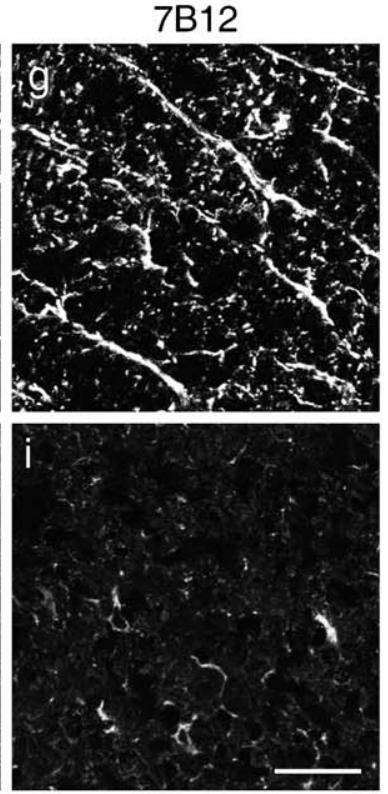

GFAP
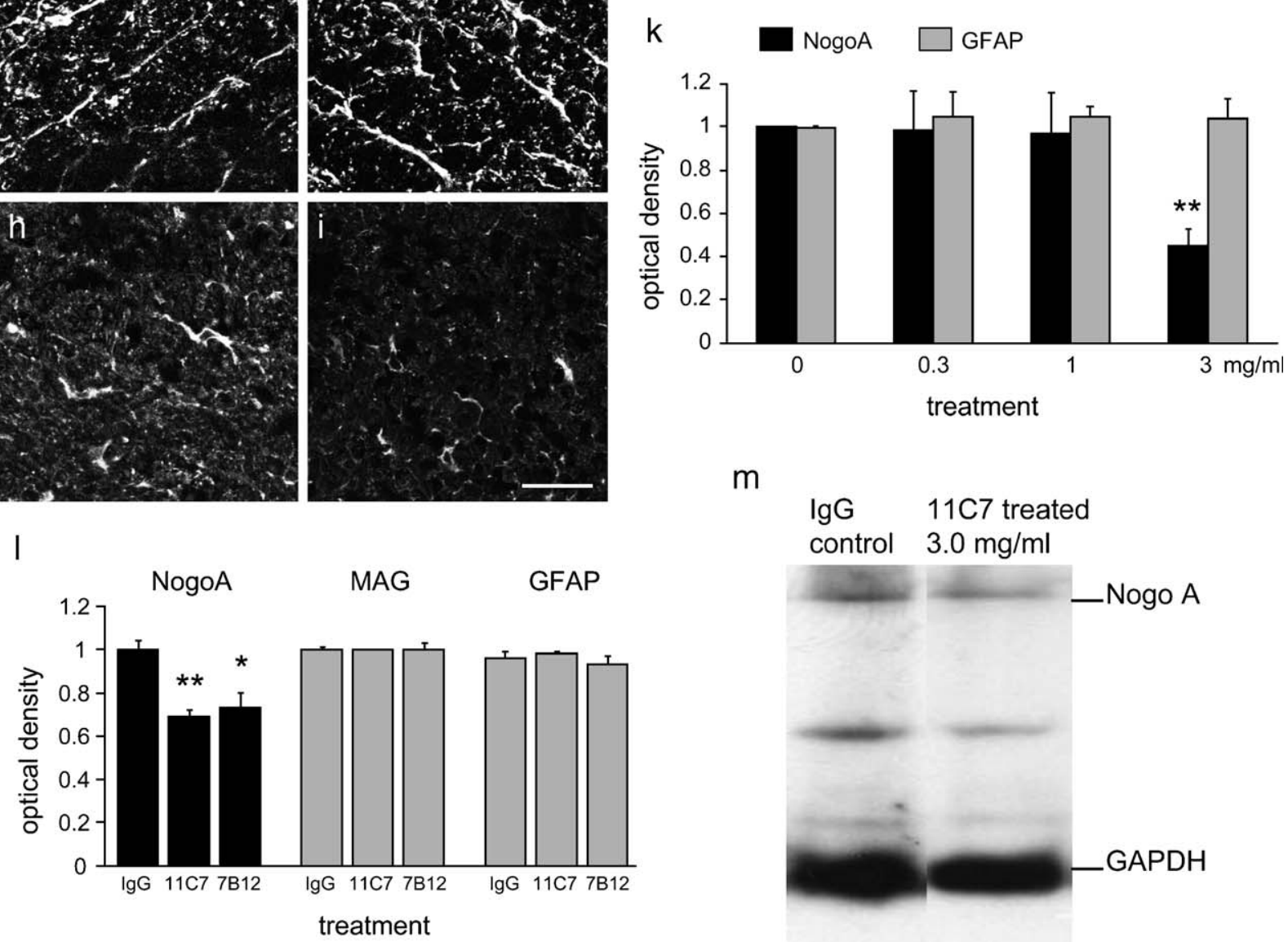

$\mathrm{m}$

IgG $\quad 11 \mathrm{C} 7$ treated control $3.0 \mathrm{mg} / \mathrm{ml}$

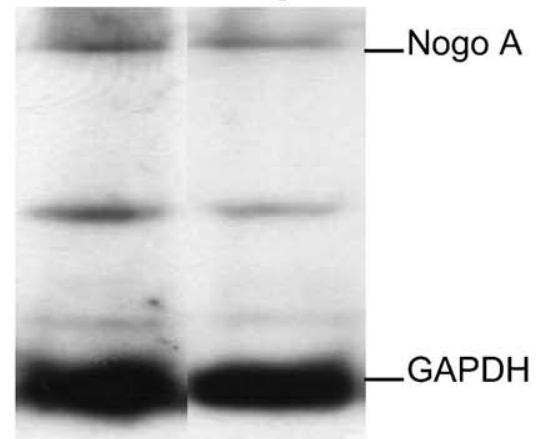


Experimental methods

\section{Antibodies}

Three monoclonal antibodies (mABs) against different sites of Nogo-A were used: $\mathrm{mAB} 11 \mathrm{C} 7$ directed against a 18 amino acid peptide (aa 623640) close to the active site of the rat Nogo-A-specific region (Oertle et al., 2003), the same region against which the neutralizing rabbit antiserum AS472 was made (Chen et al., 2000). mAB 7B12 has an epitope towards the C-terminus of the Nogo-A-specific region (in the range of aa 760-820) and is also a neutralizing antibody (Oertle et al., 2003; Liebscher et al., 2005). Both mABs bind to the outer surface of living cultured oligodendrocytes (Oertle et al., 2003). In the monkey experiments, we used $\mathrm{mAB}$ hNogo-A which is a humanized monoclonal antibody raised against the Nogo-A-specific region of the human Nogo-A sequence. It recognizes human and primate Nogo-A specifically on Western blots (data not shown). All antibodies were purified as IgGs and concentrated to $3 \mathrm{mg} /$ $\mathrm{ml}$ in PBS. In some of the experiments, the mAB IN-1 (Caroni and Schwab, 1988; Chen et al., 2000) was used. It was applied by injection of hybridoma cells into the parietal cortex as described by Schnell and Schwab (Schnell et al., 1990).

Control antibodies: mouse serum derived IgG (Chemicon Int., Temecula/CA, USA) or a mAB directed against wheat auxin (AMS Biotechnology, Oxon/UK) was used as control treatments. For hybridoma AB controls, an anti-HRP antibody was used (Schnell et al., 1990).

\section{Neurite outgrowth assay}

Brainstems of adult Cynomolgus monkeys (15 kg body weight) were rapidly dissected and homogenized with CHAPS; a membrane protein extract was then prepared as described (Spillmann et al., 1998). The extract was adsorbed overnight at $1-20 \mu \mathrm{g}$ protein per $\mathrm{cm}^{2}$ culture dish on Greiner 4-well dishes (Greiner, Nürtingen, Germany). Dishes were washed three times with warm Hank's solution before plating the neurons. The monoclonal antibodies 11C7, 7B12 (Oertle et al., 2003) or mAB hNogoA or a control mouse IgG were preincubated on the dishes at $0.1,1$, or 10 $\mu \mathrm{g} / \mathrm{ml}$ for $30 \mathrm{~min}$ and subsequently removed. Postnatal day (P) 6-7 rat cerebellar granule cells were prepared as described by Niederöst et al. (1999) and plated at 50,000 cells $/ \mathrm{cm}^{2}$. Cells were cultured for $24 \mathrm{~h}$ in serum-free medium, fixed, and immunostained for the microtubule associated protein MAP 1b (Chemicon monoclonal AB, 1:2000) (Gordon-Weeks and Fischer, 2000). Four fields at a defined distance to the edge of the well were quantified for each well using a $40 \times$ objective by placing a horizontal line through the center of the observation field and counting all intersections of neurites with the line. All cell bodies touching the line were also counted, and an outgrowth index (neurites per cell body; reflects neurite length and number) was calculated for each well. All counts were done blindly on coded experiments.

\section{Neurons and oligodendrocytes grown with anti-Nogo}

antibody: cell culture and immunocytochemistry

Primary cultures of embryonic day (E)18 rat hippocampal neurons were grown at a density of $1.5 \times 10^{4}$ per $18 \mathrm{~mm}^{2}$ glass coverslip in Neurobasal medium (Gibco/Invitrogen) supplemented with B27 supplement (Gibco/ Invitrogen), $0.5 \mathrm{mM} \mathrm{L}$-glutamine, and $1.25 \mathrm{mg} / \mathrm{ml}$ gentamicin. The coverslips were placed over a glial feeder cell layer. Hippocampal cultures were treated with antibody $11 \mathrm{C} 7$ or control $\mathrm{IgG}$ at $30 \mu \mathrm{g} / \mathrm{ml}$ immediately after plating followed by "booster doses" $(3 \mu \mathrm{g} / \mathrm{ml})$ every fourth day. Cells were processed for immunocytochemistry for Nogo-A after 14 days in vitro.

Primary cultures of rat oligodendrocytes were prepared from dissected $\mathrm{P}$ 6-8 optic nerves. Oligodendrocytes were grown in a high glucose and sodium pyruvate medium containing several additives including insulin, triiodothyronine hormone, horse serum, and gentamicin. Oligodendrocyte cultures were treated with antibodies $11 \mathrm{C} 7$ or control $\operatorname{IgG}(30 \mu \mathrm{g} / \mathrm{ml})$ after $36 \mathrm{~h}$ in culture. Cells were processed for immunocytochemistry after 5 days in vitro.
Nogo-A was immunocytochemically detected as described previously (Dodd et al., 2005). Briefly, cells were fixed using 4\% paraformaldehyde and permeabilized using $0.3 \%$ Triton X-100. Upon permeabilization, cells were incubated with a purified rabbit antiserum against Nogo-A (Oertle et al., 2003), and the primary antibody was detected using a TRITC-conjugated secondary antibody. Oligodendrocytes costained for F-actin using phalloidin showed the typical radial morphology. Densitometry of the immunostained cells was performed on oligodendrocytes and hippocampal cells using the ImageJ software. In all densitometric measurements, the cell body was included as the region of interest.

\section{SDS-gels and Western blotting}

Tissues were homogenized and extracted on ice in $20 \mathrm{mM}$ Tris $-\mathrm{Cl}$, $\mathrm{pH} 7.4$, with $1 \mathrm{mM}$ EDTA, $150 \mathrm{mM} \mathrm{NaCl}, 1 \% \mathrm{NP}-40$ and $0.1 \% \mathrm{Na}-$ deoxycholate. Lysates were clarified by centrifugation at $2000 \mathrm{rpm}$ for $15 \mathrm{~min}$, and the detergent-soluble supernatant was saved for further analysis.

Aliquots (20 $\mu \mathrm{g}$ of protein) of tissue lysates were separated by SDSPAGE under reducing conditions and transferred to Immobilon Pmembranes (PVDF; $0.45 \mu \mathrm{m}$; Millipore). Membranes were incubated in TBST blocking solution (TBS, pH 7.4, 0.1\% (vol/vol) Tween-20 and 3\% (wt/vol) TopBlock), followed by incubation overnight in $1.5 \%$ blocking solution with a rabbit antiserum against the Nogo-A/B common N-terminus (AS Bianca) (Oertle et al., 2003). After washing in TBST, membranes were incubated with HRP-coupled secondary antibody, washed, incubated in 3\% blocking solution, and incubated overnight with the primary antibody antiGAPDH (Abcam; 1:5000). After incubation with the HRP-coupled secondary antibody, the signals were detected by SuperSignal West Pico Chemiluminescent Substrate (Pierce). SeeBlue Plus2 Prestained Standard (Invitrogen) was used to determine the protein size. Autoradiograms were quantified by Scion Image (Scion Corporation), normalizing the data to GAPDH expression values.

\section{Animals}

Adult $200 \mathrm{~g}$ female Lewis rats $(n=18)$ were used for intrathecal and intraventricular infusions of antibodies in intact or spinal cord lesioned animals. Adult male Fisher CDF344 rats $(n=17)$ were used for the stroke experiments.

Two male adult Macaque monkeys (Macaca fascicularis) were used in this study for intrathecal infusion of the humanized antibody hNogo-A against human Nogo-A. The monkeys, with intact spinal cord, were 7.5 and 8 years old at the time of the experiment and weighed around $15 \mathrm{~kg}$.

All the surgical procedures and animal care were conducted in accordance with the Guide for the Care and Use of Laboratory Animals (ISBN 0-309-05377-3; 1996) and approved by the local veterinary authorities.

\section{Surgical procedures in rats}

\section{Pump implantations}

Alzet 2ML2 pumps (Alza Corporation, Palo Alto, USA) were used for all the experiments. Pumps were implanted under the back skin of rats, and catheters were lead to an Alzet intraventricular infusion cannula cemented on the skull over the ventricle opposite to the stroke lesion (in case of stroke). For intrathecal infusions, very fine (32 gauge) catheters (CR3218, ReCathCo, LLC, 2853-106 Oxford Boulevard, Allison Park, PA 15101) were introduced into the subdural space over the spinal cord by a L2 laminectomy. Catheters were pushed up to the midthoracic region. They were secured to the L3 bone to prevent extrusion. Pumps contained antibodies at a concentration of $3 \mathrm{mg}$ / $\mathrm{ml}$ in PBS. Pumps delivered $5 \mu \mathrm{l} / \mathrm{h}$.

\section{Spinal cord lesions}

Rats were anesthetized with subcutaneous injection of Hypnorm (Janssen Pharmaceutics, Beerse, Belgium, $120 \mu \mathrm{l}$ per $200 \mathrm{~g}$ body weight) and Dormicum (Roche Pharmaceuticals, Basle, $\mathrm{CH}, 0.75 \mathrm{mg}$ in $150 \mu \mathrm{l}$ per 
$200 \mathrm{~g}$ body weight). Vitamin A containing eye ointment (Blache, Chauvin Novopharme AG, Switzerland) was applied to protect the eyes from dehydration during the relatively long operation procedure.

A bilateral section of the dorsal and dorsolateral funiculus and the dorsal horn at the spinal level T8 was applied as described earlier (Brosamle et al., 2000).

Stroke

Rats (male, Fisher CDF344, $250 \mathrm{~g}$ ) were anesthetized with 2\% isoflurane in a 70/30 (by vol) nitrous oxide/oxygen mixture. The right or left middle cerebral artery (MCA) and its lenticulostriate branches were permanently occluded by bipolar electrocoagulation as described previously (Wiessner et al., 2000). Antibodies were administered $24 \mathrm{~h}$ after MCA occlusion. For icv delivery, a brain infusion cannula (Alzet ${ }^{\circledR}$ brain infusion kit) was stereotaxically implanted under anesthesia in the intact lateral ventricle (coordinates: lateral 1.3; anterior-posterior -0.8 ; dorsoventral -3.8 , relative to Bregma) and connected to an Alzet 2ML2 pump.

\section{Surgical procedures in monkeys}

Preanesthesia was induced by i.m. injection of ketamine (Ketalan ${ }^{\circledR}$; Parke-Davis, $5 \mathrm{mg} / \mathrm{kg}$ ), followed by atropine $(0.05 \mathrm{mg} / \mathrm{kg}$, i.m.) to reduce bronchial secretions. Before surgery, performed under aseptic conditions, the animal was treated with the analgesic Carprofen $\left(\right.$ Rymadil $^{\circledR}, 4 \mathrm{mg} / \mathrm{kg}$, s.c.). An intravenous catheter was placed in the femoral vein for continuous perfusion with a mixture of Propofol $1 \%$ (Fresenius ${ }^{\circledR}$ ) and glucose $4 \%$ solution ( $1 \mathrm{vol}$ of Propofol and 2 vol of glucose solution), inducing a deep anesthesia. The animal was then placed in a stereotaxic frame using ear bars. Heart rate, respiration rate, expired $\mathrm{CO}_{2}$, arterial $\mathrm{O}_{2}$ saturation, and body temperature were continuously monitored.

The animal was placed in a ventral position, and midline skin incision was performed from $\mathrm{C} 2$ to Th1. A complete C6 laminectomy and an upper C7 hemi-laminectomy were then performed. The ligamentum flavum was removed. The dura mater was exposed and incised longitudinally above the 7 th and the 8th cervical spinal segments, corresponding to the rostral zone of the spinal portion covered by the 6 th cervical lamina. A polyethylene tube (10 cm long), connected to an osmotic pump (Alzet $\left.{ }^{\circledR}, 2 \mathrm{ML} 1\right)$ delivering the hNogo-A antibody, was inserted below the dura, pushed a few $\mathrm{mm}$ rostrally and attached to the dura with a suture. The osmotic pump was placed and secured in a cavity made in the mass of back muscles a few centimeters lower than the laminectomy, on the left side. The tube was secured along its trajectory with sutures to muscle tissue. The muscles and the skin were sutured, and the animals recovered from anesthesia 15-30 min after interruption of the infusion with Profolol. The animals were treated postoperatively with an antibiotic (Ampiciline $10 \%, 30 \mathrm{mg} / \mathrm{kg}$, s.c.). Additional doses of Carprofen were given daily during 1 week (pills of Rymadil mixed with food).

The monkeys were sacrificed 7 days after implantation of the osmotic pump. Sedation was first induced with ketamine, as mentioned above, followed by a deep anesthesia obtained by i.p. injection of a lethal dose of pentobarbital $(90 \mathrm{mg} / \mathrm{kg})$. The animals were perfused transcardially with 0.4 1 of $0.9 \%$ saline, followed by 41 of fixative $(4 \%$ solution of paraformaldehyde in $0.1 \mathrm{M}$ phosphate buffer, $\mathrm{pH}$ 7.6). Perfusion was continued with 3 solutions of sucrose of increasing concentration (10\% in fixative, $20 \%$ and $30 \%$ in phosphate buffer).

\section{Histological procedures, immunofluorescence and histochemistry}

Rats were fixed under deep Nembutal anesthesia by perfusion through the heart with $4 \%$ buffered paraformaldehyde. Brains and spinal cords of rats and monkeys were carefully dissected, cryoprotected in 30\% sucrose and sectioned at $40 \mu \mathrm{m}$ in a cryostat. For all stainings, we used free floating sections, mostly in a transverse (spinal cord) or coronal (brain) plane.

Detection of infused mABs: rat-adsorbed anti-mouse antibodies coupled to biotin were used for $\mathrm{mAB} 11 \mathrm{C} 7$ and 7B12 (Jackson ImmunoResearch
Laboratories, West Grove, PA, USA). An anti-human secondary antibody was used for the mAB hNogo-A. For double labeling, the following antibodies were used: the rabbit AS472 (affinity purified) for endogenous Nogo-A (Chen et al., 2000), rabbit antibodies against GFAP for astrocytes (Dako, Carpinteria, CA, USA), and a rabbit antibody against cathepsin-D (Dako) for lysosome localization. All the antisera were visualized by TRITCor FITC-coupled corresponding secondary antibodies, or using the ABCDAB system (Vector Laboratories, Burlingame, CA, USA).

Sections were analyzed by epifluorescence on a Zeiss Axiophot Microscope or by confocal microscopy (ZEISS LSM 410). For quantitative determination of endogenous Nogo-A levels, sections from 10 coded, randomly mixed rats with different treatments were reacted together identically for Nogo-A using biotinylated secondary antibodies followed by the $\mathrm{ABC}$ complex, washed and visualized with $\mathrm{DAB}$. Background corrected optical density of the reaction product was quantified using the NIH Image program (scion) from digital images of ventral grey and white matter regions of the spinal cord.

\section{Acknowledgments}

We thank Roland Schoeb for his help with the preparation of the figures and Silvia Kaufmann for her help with the manuscript. The study was supported by the Swiss National Science Foundation (Grant No. 31-63633), the NSF National Competence Center for Research on Neural Plasticity and Repair, and the Christopher Reeve Foundation, Springfield, NJ.

\section{References}

Benowitz, L.I., Perrone-Bizzozero, N.I., 1991. The expression of GAP-43 in relation to neuronal growth and plasticity: when, where, how, and why? Prog. Brain Res. 89, 69-87.

Bieber, A., Asakura, K., Warrington, A., Kaveri, S.V., Rodriguez, M., 2000. Antibody-mediated remyelination: relevance to multiple sclerosis. Mult. Sclerosis 6, S1-S5.

Brosamle, C., Huber, A.B., Fiedler, M., Skerra, A., Schwab, M.E., 2000. Regeneration of lesioned corticospinal tract fibers in the adult rat induced by a recombinant, humanized IN-1 antibody fragment. J. Neurosci. 20, $8061-8068$.

Caroni, P., Schwab, M.E., 1988. Antibody against myelin-associated inhibitor of neurite growth neutralizes nonpermissive substrate properties of CNS white matter. Neuron 1, 85-96.

Charles, P., Hernandez, M.P., Stankoff, B., Aigrot, M.S., Colin, C., Rougon, G., Zalc, B., Lubetzki, C., 2000. Negative regulation of central nervous system myelination by polysialylated-neural cell adhesion molecule. Proc. Natl. Acad. Sci. U. S. A. 97, 7585-7590.

Chen, M.S., Huber, A.B., van der Haar, M.E., Frank, M., Schnell, L., Spillmann, A.A., Christ, F., Schwab, M.E., 2000. Nogo-A is a myelinassociated neurite outgrowth inhibitor and an antigen form monoclonal antibody IN-1. Nature 403, 434-439.

Delbruck, R., Desel, C., von Figura, K., Hille-Rehfeld, A., 1994. Proteolytic processing of cathepsin D in prelysosomal organelles. Eur. J. Cell Biol. 64, 7-14.

Dodd, D.A., Niederoest, B., Bloechlinger, S., Dupuis, L., Loeffler, J.-P., Schwab, M.E., 2005. Nogo-A., -B and -C are found on the cell surface and interact together in many different cell types. J. Biol. Chem. 280, $12494-12502$.

Domeniconi, M., Cao, Z., Spencer, T., Sivasankaran, R., Wange, K.C., Nikulina, E., Kimura, N., Cai, H., Deng, K., Gao, Y., He, Z., Filbin, M.T., 2002. Myelin-associated glycoprotein interacts with the Nogo66 receptor to inhibit neurite outgrowth. Neuron 35, $283-290$

During, M.J., Symes, C.W., Lawlor, P.A., Lin, J., Dunning, J., Fitzsimons, H.L., Poulsen, D., Leone, P., Yu, R., Dicker, B.L., Lipski, J., Young, D., 
2000. An oral vaccine against NMDAR1 with efficacy in experimental stroke and epilepsy. Science 287, 1453-1460.

Dyer, J.K., Bourque, J.A., Steeves, J.D., 1998. Regeneration of brainstemspinal axons after lesion and immunological disruption of myelin in adult rat. Exp. Neurol. 154, 12-22.

Filbin, M.T., 2003. Myelin-associated inhibitors of axonal regeneration in the adult mammalian CNS. Nat. Rev., Neurosci. 4, 703-713.

Friedman, L.M., Rinon, A., Schechter, B., Lyass, L., Lavi, S., Bacus, S.S., Sela, M., Yarden, Y., 2005. Synergistic down-regulation of receptor tyrosine kinases by combinations of mABs: implications for cancer immunotherapy. Proc. Natl. Acad. Sci. U. S. A. A 102, 1915-1920.

Gelinas, D.S., DaSilva, K., Fenili, D., St.George-Hyslop, P., McLaurin, J., 2004. Immunotherapy for Alzheimer's disease. Proc. Natl. Acad. Sci. U. S. A. 101, 14657-14662.

Goldberg, J.L., Vargas, M.E., Wang, J.T., Mandemakers, W., Oster, S.F., Sretavan, D.W., Barres, B.A., 2004. An oligodendrocyte lineagespecific semaphorin, Sema5A, inhibits axon growth by retinal ganglion cells. J. Neurosci. 24, 4989-4999.

Goldman, D.L., Casadevall, A., Zuckier, L.S., 1997. Pharmacokinetics and bio distribution of a monoclonal antibody to Cryptococcus neoformans capsular polysaccharide antigen in a rat model of cryptococcal meningitis: implications for passive immunotherapy. J. Med. Vet. Mycol. 35, 271-278.

Gordon-Weeks, P.R., Fischer, I., 2000. MAP1B expression and microtubule stability in growing and regenerating axons. Microsc. Res. Tech. 48, $63-74$.

GrandPré, T., Nakamura, F., Vartanian, T., Strittmatter, S.M., 2000. Identification of the Nogo inhibitor of axon regeneration as a reticulon protein. Nature 403, 439-444.

GrandPré, T., Li, S., Strittmatter, S.M., 2002. Nogo-66 receptor antagonist peptide promotes axonal regeneration. Nature 417, 547-551.

Hock, C., Konietzko, U., Streffer, J.R., Tracy, J., Signorell, A., MüllerTillmanns, B., Lemke, U., Henke, K., Moritz, E., Garcia, E., Wollmer, M.A., Umbricht, D., de Quervain, D.J.F., Hofmann, M., Maddalena, A., Papassotiropoulos, A., Nitsch, R.M., 2003. Antibodies against betaamyloid slow cognitive decline in Alzheimer's disease. Neuron 38, $547-554$.

Huber, A.B., Weinmann, O., Brosamle, C., Oertle, T., Schwab, M.E., 2002. Patterns of Nogo mRNA and protein expression in the developing and adult rat and after CNS lesions. J. Neurosci. 22, 3553-3567.

Hunt, D., Mason, M.R.J., Campbell, G., Coffin, R., Anderson, P.N., 2002. Nogo receptor mRNA expression in intact and regenerating CNS neurons. Mol. Cell. Neurosci. 20, 537-552.

Josephson, A., Widenfalk, J., Widmer, H.W., Olson, L., Spenger, C., 2001. Nogo mRNA expression in adult and fetal human and rat nervous tissue and in weight drop injury. Exp. Neurol. 169, 319-328.

Kapfhammer, J.P., Schwab, M.E., 1994. Inverse pattern of myelination and GAP-43 expression in the adult CNS: neurite growth inhibitors as regulators of neuronal plasticity? J. Comp. Neurol. 340, 194-206.

Keirstead, H.S., Hasan, S.J., Muir, G.D., Steeves, J.D., 1992. Suppression of the onset of myelination extends the permissive period for the functional repair of embryonic spinal cord. Proc. Natl. Acad. Sci. U. S. A. $89,11664-11668$

Kim, J.E., Li, S., GrandPre, T., Qiu, D., Strittmatter, S.M., 2003. Axon regeneration in young adult mice lacking Nogo-A/B. Neuron 38, $187-199$

Li, S., Strittmatter, S.M., 2003. Delayed systemic Nogo-66 receptor antagonist promotes recovery from spinal cord injury. J. Neurosci. 15, $4219-4227$.

Liebscher, T., Schnell, L., Schnell, D., Scholl, J., Schneider, R., Gullo, M., Fouad, K., Mir, A., Rausch, M., Kindler, D., Hamers, F.P.T., Schwab, M.E., 2005. Nogo-A antibody improves regeneration and locomotion of spinal cord-injured rats. Ann. Neurol. 58, 706-719.

Liu, B.P., Fournier, A., GrandPré, T., Strittmatter, S.M., 2002. Myelinassociated glycoprotein as a functional ligand for the Nogo-66 receptor. Science 297, 1190-1193.

McKerracher, L., David, S., Jackson, D.L., Kottis, V., Dunn, R.J., Braun,
P.E., 1994. Identification of myelin-associated glycoprotein as a major myelin-derived inhibitor of neurite growth. Neuron 13, 805-811.

Merkler, D., Metz, G.A.S., Raineteau, O., Dietz, V., Schwab, M.E., Fouad, K., 2001. Locomotor recovery in spinal cord-injured rats treated with an antibody neutralizing the myelin-associated neurite growth inhibitor Nogo-A. J. Neurosci. 21, 3665-3673.

Merkler, D., Oertle, T., Buss, A., Pinschewer, D.D., Schnell, L., Bareyre, F.M., Kerschensteiner, M., Buddeberg, B.S., Schwab, M.E., 2003. Rapid induction of autoantibodies against Nogo-A and MOG in the absence of an encephalitogenic $\mathrm{T}$ cell response: implication for immunotherapeutic approaches in neurological diseases. FASEB J. 17, $2275-2277$.

Moreau-Fauvarque, C., Kumanogoh, A., Camand, E., Jaillard, C., Barbin, G., Boquet, I., Love, C., Jones, E.Y., Kikutani, H., Lubetzki, C., Dusart, I., Chédotal, A., 2003. The transmembrane semaphorin Sema4D/CD100, an inhibitor of axonal growth, is expressed on oligodendrocytes and upregulated after CNS lesion. J. Neurosci. 23, 9229-9239.

Mukhopadhyay, G., Doherty, P., Walsh, F.S., Crocker, P.R., Filbin, M.T., 1994. A novel role of myelin-associated glycoprotein as an inhibitor of axonal regeneration. Neuron 13, 1-20.

Niederöst, B., Zimmermann, D.R., Schwab, M.E., Bandtlow, C.E., 1999. Bovine CNS myelin contains neurite growth-inhibitory activity associated with chondroitin sulfate proteoglycan. J. Neurosci. 19, 8979-8989

Oertle, T., van der Haar, M.E., Bandtlow, C.E., Robeva, A., Burfeind, P., Buss, A., Huber, A.B., Simonen, M., Schnell, L., Brosamle, C., Kaupmann, K., Vallon, R., Schwab, M.E., 2003. Nogo-A inhibits neurite outgrowth and cell spreading with three discrete regions. J. Neurosci. 23, 5393-5406.

Papadopoulos, C.M., Tsai, S.-Y., Aslbiei, T., O’Brien, T.E., Schwab, M.E., Kartje, G.L., 2002. Functional recovery and neuroanatomical plasticity following middle cerebral artery occlusion and IN-1 antibody treatment in the adult rat. Ann. Neurol. 51, 433-441.

Papanastassiou, V., Pizer, B.L., Chandler, C.L., Zananiri, T.F., Kemshead, J.T., Hopkins, K.I., 1995. Pharmacokinetics and dose estimated following intrathecal administration of 1311-monoclonal antibodies for the treatment of central nervous system malignancies. Int. J. Radiat. Oncol., Biol., Phys. 31, 541-552.

Qian, X., O'Rourke, D.M., Drebin, J., Zhao, H., Wang, Q., Greene, M.I., 1997. Identification of $\mathrm{p} 185 \mathrm{neu}$ sequences required for monoclonal antibody- or ligand-mediated receptor signal attenuation. DNA Cell Biol. 16, 1395-1405.

Raineteau, O., Schwab, M.E., 2001. Plasticity of motor systems after incomplete spinal cord injury. Nat. Rev., Neurosci. 2, 263-274.

Savio, T., Schwab, M.E., 1990. Lesioned corticospinal tract axons regenerate in myelin-free rat spinal cord. Proc. Natl. Acad. Sci. U. S. A. $87,4130-4133$.

Schnell, L., Schwab, M.E., 1990. Axonal regeneration in the rat spinal cord produced by an antibody against myelin-associated neurite growth inhibitors. Nature 343, 269-272.

Schwab, M.E., 2004. Nogo and axon regeneration. Curr. Opin. Neurobiol. $14,118-124$.

Simonen, M., Pedersen, V., Weinmann, O., Schnell, L., Buss, A., Ledermann, B., Christ, F., van der Putten, M., Schwawb, M.E., 2003. Systemic deletion of the myelin-associated outgrowth inhibitor Nogo-A improves regenerative and plastic responses after spinal cord injury. Neuron 38, 201-211.

Spillmann, A.A., Bandtlow, C.E., Lottspeich, F., Keller, F., Schwab, M.E., 1998. Identification and characterization of a bovine neurite growth inhibitor (bNI-220). J. Biol. Chem. 273, 19283-19293.

Stempien, L., Tsai, T., 2000. Intrathecal baclofen pump use for spasticity: a clinical survey. Am. J. Phys. Med. Rehabil. 79, 536-541.

Thallmair, M., Metz, G.A.S., Z'Graggen, W.J., Raineteau, O., Kartje, G.L., Schwab, M.E., 1998. Neurite growth inhibitors restrict plasticity and functional recovery following corticospinal tract lesions. Nat. Neurosci. $1,124-131$ 
Thomas, L.B., Book, A.A., Schweitzer, J.B., 1991. Immunohistochemical detection of a monoclonal antibody directed against the NGF receptor in basal forebrain neurons following intraventricular injection. J. Neurosci. Methods 37, 37-45.

Tolbert, L.M., Lameh, J., 1998. Antibody to epitope tag induces internalization of human muscarinic subtype 1 receptor. J. Neurochem. $70,113-119$.

Trapp, B.D., Quarles, R.H., Suzuki, K., 1984. Immunocytochemical studies of quaking mice support a role for the myelin-associated glycoprotein in forming and maintaining the periaxonal space and periaxonal cytoplasmic collar of myelinating Schwann cells. J. Cell Biol. 99, 594-606.

Turner, M.S., 2003. Intrathecal drug delivery 2002. Acta Neurochir., Suppl. $87,29-35$.

Wang, K.C., Kim, J.A., Sivasankaran, R., Segal, R., He, Z., 2002. p75 interacts with the Nogo receptor as a co-receptor for Nogo, MAG and OMgp. Nature 420, 74-78.

Wang, X., Chun, S.-J., Treloar, H., Vartanian, T., Greer, C.A., Strittmatter,
S.M., 2002. Localization of Nogo-A and Nogo-66 receptor proteins at sites of axon-myelin and synaptic contact. J. Neurosci. 22, 5505-5515. Warrington, A.E., Asakura, K., Bieber, A.J., Ciric, B., Van Keulen, V., Kaveri, S.V., Kyle, R.A., Pease, L.R., Rodriguez, M., 2000. Human monoclonal antibodies reactive to oligodendrocytes promote remyelination in a model of multiple sclerosis. Proc. Natl. Acad. Sci. U. S. A. $97,6820-6825$.

Wiessner, C., Sauer, D., Alaimo, D., Allegrini, P.R., 2000. Protective effect of a caspase inhibitor in models for cerebral ischemia in vitro and in vivo. Cell. Mol. Biol. 46, 53-62.

Wiessner, C., Bareyre, F.M., Allegrini, P.R., Mir, A.K., Frentzel, S., Zurini, M., Schnell, L., Oertle, T., Schwab, M.E., 2003. Anti-Nogo-A antibody infusion 24 hours after experimental stroke improved behavioral outcome and corticospinal plasticity in normotensive and spontaneously hypertensive rats. J. Cereb. Blood Flow Metab. 23, 154-165.

Zhang, Y., Pardridge, W.M., 2001. Mediated efflux of IgG molecules from brain to blood across the blood-brain barrier. J. Neuroimmunol. 114, $168-172$. 